\title{
Lutetium Disilicate Coating on Silicon Nitride for High Temperature Oxidation Resistance
}

\author{
Tomohiro SUETSUNA, Masato ISHIZAKI, Motohide ANDO, Naoki KONDO,* \\ Tatsuki OHJI* and Shuzo KANZAKI* \\ Synergy Ceramics Laboratory, Fine Ceramics Research Association, 2268-1, Shimo-Shidami, Moriyama-ku, Nagoya-shi $463-8687$ \\ *Synergy Materials Research Center, National Institute of Advanced Industrial Science and Technology, \\ 2268-1, Shimo-Shidami, Moriyama-ku, Nagoya-shi 463-8687
}

\author{
$\mathrm{Lu}_{2} \mathrm{Si}_{2} \mathrm{O}_{7}$ コーティングによる窒化ケイ素の高温酸化抑制効果 \\ 末綱倫浩·石崎雅人 ·安藤元英·近藤直樹*·大司達樹* ·神崎修三* \\ ファインセラミックス技術研究組合シナジーセラミックス研究所, 463-8687 名古屋市守山区下志段味字穴ヶ洞 2268-1 \\ *産業技術総合研究所シナジーマテリアル研究センター，463-8687 名古屋市守山区下志段味字穴ヶ洞 2268-1
}

\begin{abstract}
Lutetium disilicate $\left(\mathrm{Lu}_{2} \mathrm{Si}_{2} \mathrm{O}_{7}\right)$ layer of 4-12 $\mu \mathrm{m}$ in thickness with a small amount of silica $\left(\mathrm{SiO}_{2}\right)$ phase was coated on silicon nitride $\left(\mathrm{Si}_{3} \mathrm{~N}_{4}\right)$ by reaction sintering after dip coating. The oxidation resistance and flexural strength of the coated sample were investigated and compared with those of the uncoated one. After cycling oxidation at $1500 \mathrm{C}$ for up to $100 \mathrm{~h}$ in air, the total weight gain of the coated sample was almost half that of the uncoated one, indicating that oxidation resistance of $\mathrm{Si}_{3} \mathrm{~N}_{4}$ was improved by about $100 \%$. The flexural strength of the coated sample was not deteriorated in comparison with that of the uncoated one, and it was also maintained after the cycling oxidation at $1500^{\circ} \mathrm{C}$ for $100 \mathrm{~h}$ in air. Those physical and chemical stabilities can be attributed to the presence of $\mathrm{Lu}_{2} \mathrm{Si}_{2} \mathrm{O}_{7}$ layer, which effectively prevents oxidation of $\mathrm{Si}_{3} \mathrm{~N}_{4}$ at high temperature.
\end{abstract}

[Received November 4, 2003; Accepted March 23, 2004]

Key-words : Lutetium disilicate, Silicon nitride, Coating, High temperature, Oxidation resistance

\section{Introduction}

$\mathrm{Si}_{3} \mathrm{~N}_{4}$ has excellent thermo-mechanical properties; high strength at elevated temperatures, low coefficient of thermal expansion, and high thermal shock resistance. ${ }^{1-3)}$ Therefore, it is one of the most promising materials for high temperature structural applications such as stator, rotor, and combustor of gas turbine engines. For example, the use of it for components of gas turbine engines would effectively improve the thermal efficiency by realizing higher operating temperature than that achieved by the conventional super-alloy materials.

However, one problem is that its oxidation resistance is relatively low at elevated temperatures $\left.\left(-1500^{\circ} \mathrm{C}\right) .{ }^{4}\right)$ When it is oxidized in air, $\mathrm{SiO}_{2}$ scale with silicate glassy and/or crystalline phases (by reacting $\mathrm{SiO}_{2}$ with grain boundary phase of $\mathrm{Si}_{3} \mathrm{~N}_{4}$ ) is formed with a cracked surface, leading to the deterioration of mechanical properties. It has been known that the oxidation resistance of $\mathrm{Si}_{3} \mathrm{~N}_{4}$ is improved by using nanoparticles such as $\mathrm{SiC}$ and $\mathrm{MoSi}_{2}$ in the grain boundary region, ${ }^{5), 6)}$ or by crystallizing the grain boundary phase. ${ }^{7)}$ However, these improvements are not sufficient, and it is necessary to further improve the oxidation resistance.

In the present research, in order to realize better oxidation resistance, $\mathrm{Si}_{3} \mathrm{~N}_{4}$ was coated with $\mathrm{Lu}_{2} \mathrm{Si}_{2} \mathrm{O}_{7}$, which had extremely high chemical stability and close coefficient of thermal expansion to that of $\mathrm{Si}_{3} \mathrm{~N}_{4}$. The sample coated with $\mathrm{Lu}_{2} \mathrm{Si}_{2} \mathrm{O}_{7}$ was fabricated by reaction sintering after dipping $\mathrm{Si}_{3} \mathrm{~N}_{4}$ substrate into $\mathrm{Lu}_{2} \mathrm{O}_{3}-\mathrm{SiO}_{2}$ slurry. This coating process is easy and applicable even to complex-shaped components. It is also more cost-effective than other methods such as the chemical vapor deposition and plasma spray, and therefore suitable for industrial applications. Two kinds of coated samples were prepared for investigating the influence of thickness of coating layer on preventing the oxidation; one is single coated sample, and the other is triple coated sample. These samples were exposed to cycling oxidation test at $1500^{\circ} \mathrm{C}$ for up to $100 \mathrm{~h}$ in air, and the weight changes and flexural strength at room temperature after the oxidation were examined.

\section{Experimental procedure}

Prior to fabricating the samples coated with $\mathrm{Lu}_{2} \mathrm{Si}_{2} \mathrm{O}_{7}$, the coefficients of thermal expansion of pure $\mathrm{Lu}_{2} \mathrm{Si}_{2} \mathrm{O}_{7}$ and $\beta$ $\mathrm{Si}_{3} \mathrm{~N}_{4}$ (same as the substrate for coating) were examined at temperatures from 30 to $1400^{\circ} \mathrm{C}$ in $\mathrm{Ar}$ atmosphere. The samples with dimensions of $3 \times 4 \times 20 \mathrm{~mm}$ were cut and ground $\left(R_{\mathrm{a}}:<0.2 \mu \mathrm{m}\right)$. The heating rate was $5^{\circ} \mathrm{C} / \mathrm{min}$, and sapphire $\left(\mathrm{Al}_{2} \mathrm{O}_{3}\right.$ single crystal $)$ was used as a reference sample.

The $\mathrm{Si}_{3} \mathrm{~N}_{4}$ used in the present research was prepared by gas pressure sintering $\left(2000^{\circ} \mathrm{C}, 4 \mathrm{~h}\right.$, under $1 \mathrm{MPa}-\mathrm{N}_{2}$ atmosphere) of $\mathrm{Si}_{3} \mathrm{~N}_{4}$ with additive system of $\mathrm{Lu}_{2} \mathrm{O}_{3}-\mathrm{SiO}_{2}$. The samples with dimensions of $3 \times 4 \times 37 \mathrm{~mm}$ were cut and ground $\left(R_{\mathrm{a}}\right.$ : $<$ $0.2 \mu \mathrm{m}$ ), and the edges of the samples were chamfered at $45^{\circ}$. The coated samples were prepared by the reaction sintering method after dipping $\mathrm{Si}_{3} \mathrm{~N}_{4}$ substrate into the slurry of $\mathrm{Lu}_{2} \mathrm{O}_{3}$ $\mathrm{SiO}_{2}\left(\mathrm{SiO}_{2} / \mathrm{Lu}_{2} \mathrm{O}_{3}=1.0\right.$; molar ratio $)$ with dispersant, binder, deformer, and water. The concentration of $\mathrm{Lu}_{2} \mathrm{O}_{3}-\mathrm{SiO}_{2}$ into the slurry was 60 mass $\%$. The dipped samples were cold isostatic pressed at $392 \mathrm{MPa}$ before reaction sintering. The reaction sintering was conducted at $1550^{\circ} \mathrm{C}$ for $20 \mathrm{~h}$ in air. The triple coated sample was prepared by repeating the abovementioned process; in the second and third coating, the mole ratio of $\mathrm{SiO}_{2} / \mathrm{Lu}_{2} \mathrm{O}_{3}$ in the slurry was 2.0.

The coated and uncoated samples were exposed to cycling oxidation at $1500^{\circ} \mathrm{C}$ in air, and the samples were weighed before and after cycling. The heating rate was $2.5^{\circ} \mathrm{C} / \mathrm{min}$, and the cooling rate was $2.8^{\circ} \mathrm{C} / \mathrm{min}$ down to $1000^{\circ} \mathrm{C}$ followed by natural cooling. It took $25 \mathrm{~h}$ for one cycle, and weight changes 
were measured in each cycle. In total, four cycles were carried out (the total oxidation time was $100 \mathrm{~h}$ ). The samples were set on the triangle pole of $\mathrm{Si}_{3} \mathrm{~N}_{4}$. The four-point flexural strength test (inner and outer spans were 10 and $30 \mathrm{~mm}$ long, respectively) was performed at a cross-head speed of $0.5 \mathrm{~mm} / \mathrm{min}$ at room temperature before and after the cycling oxidation. Four samples were used for each measurement. The microstructures and compositions of the samples were examined by scanning electron microscopy (SEM), energy dispersive spectroscopy, and X-ray diffractometry (XRD).

\section{Results and discussion}

Figure 1 shows the coefficients of thermal expansion of pure $\mathrm{Lu}_{2} \mathrm{Si}_{2} \mathrm{O}_{7}$ and $\beta-\mathrm{Si}_{3} \mathrm{~N}_{4}$ at temperatures from 30 to $1400^{\circ} \mathrm{C}$ in $\mathrm{Ar}$ atmosphere. In this temperature range their coefficients were very close and the maximum difference was $0.6 \times 10^{-6}$ ${ }^{\circ} \mathrm{C}^{-1}$ at $300^{\circ} \mathrm{C}$, indicating very small mismatch of thermal expansion between $\mathrm{Lu}_{2} \mathrm{Si}_{2} \mathrm{O}_{7}$ and $\beta-\mathrm{Si}_{3} \mathrm{~N}_{4}$. Therefore, $\mathrm{Lu}_{2} \mathrm{Si}_{2} \mathrm{O}_{7}$ is considered to be suitable for coating $\beta-\mathrm{Si}_{3} \mathrm{~N}_{4}$ without delamination.

The slurry composition of $\mathrm{SiO}_{2} / \mathrm{Lu}_{2} \mathrm{O}_{3}$ for the first coating was 1.0 (molar ratio), which was less than the stoichiometric composition of $\mathrm{Lu}_{2} \mathrm{Si}_{2} \mathrm{O}_{7}\left(\mathrm{SiO}_{2} / \mathrm{Lu}_{2} \mathrm{O}_{3}=2.0\right)$, because $\mathrm{SiO}_{2}$ was formed by the oxidation of $\mathrm{Si}_{3} \mathrm{~N}_{4}$ in sintering process of the coating layer. After reaction sintering, single coated and triple coated samples had $\mathrm{Lu}_{2} \mathrm{Si}_{2} \mathrm{O}_{7}$ layers with a thickness of about $4 \mu \mathrm{m}$ and $12 \mu \mathrm{m}$ on the $\mathrm{Si}_{3} \mathrm{~N}_{4}$ substrate, respectively (Fig. 2). These layers were relatively dense with a few pores

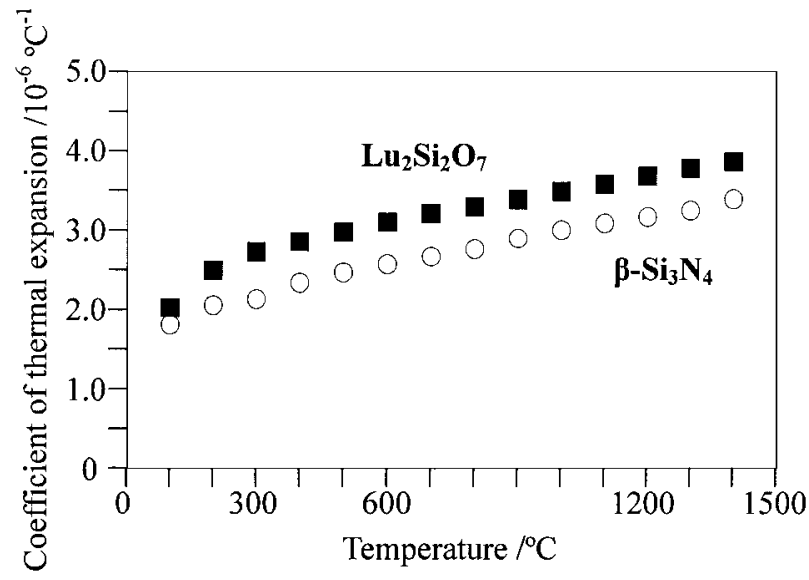

Fig. 1. Coefficients of thermal expansion of $\beta-\mathrm{Si}_{3} \mathrm{~N}_{4}(\bigcirc)$ and $\mathrm{Lu}_{2} \mathrm{Si}_{2} \mathrm{O}_{7}$ and jointed to the substrate, containing a small amount of $\mathrm{SiO}_{2}$ phase. This phase was formed between the coating layer and substrate by the oxidation of the substrate during the sintering of $\mathrm{Lu}_{2} \mathrm{Si}_{2} \mathrm{O}_{7}$.

The weight gains of the uncoated and coated samples are shown as a function of square root of time in Fig. 3. The plots of all the samples deviated somewhat from the linearity, the deviation being more pronounced in the case of the coated samples, indicating the weight grain did not obey a pure parabolic law $\left(\Delta m^{2}=k t ; \Delta m\right.$ : weight change, $k$ : parabolic oxidation rate constant, $t$ : time), which is most often used for describing oxidation behavior. This deviation can be presumably attributed mainly to the diffusion of $\mathrm{SiO}_{2}$ phase to the samples from the triangle pole of $\mathrm{Si}_{3} \mathrm{~N}_{4}$ during oxidation, which was used for setting the samples. The total weight gains of the coated samples (single coating: $0.11 \mathrm{mg} / \mathrm{cm}^{2}$, triple coating: $\left.0.099 \mathrm{mg} / \mathrm{cm}^{2}\right)$ were almost half that of the uncoated sample $\left(0.18 \mathrm{mg} / \mathrm{cm}^{2}\right)$, indicating that oxidation resistance of $\mathrm{Si}_{3} \mathrm{~N}_{4}$ was improved by about $100 \%$. The small weight gains of the coated samples were caused by the diffusion of oxygen through a few pores in the $\mathrm{Lu}_{2} \mathrm{Si}_{2} \mathrm{O}_{7}$ layer. The total weight gain of the triple coated sample was less than that of the single coated one. However, the difference in the total weight gains between the single and triple coated samples was relatively small, indicating small influence of the thickness of the coating layer on preventing the oxidation. Figure 4 shows the XRD patterns of the surface of the uncoated and triple coated samples before and after the oxidation test at $1500^{\circ} \mathrm{C}$ for $100 \mathrm{~h}$ in air. In the case of the uncoated sample, $\mathrm{SiO}_{2}$ and $\mathrm{Lu}_{2} \mathrm{Si}_{2} \mathrm{O}_{7}$

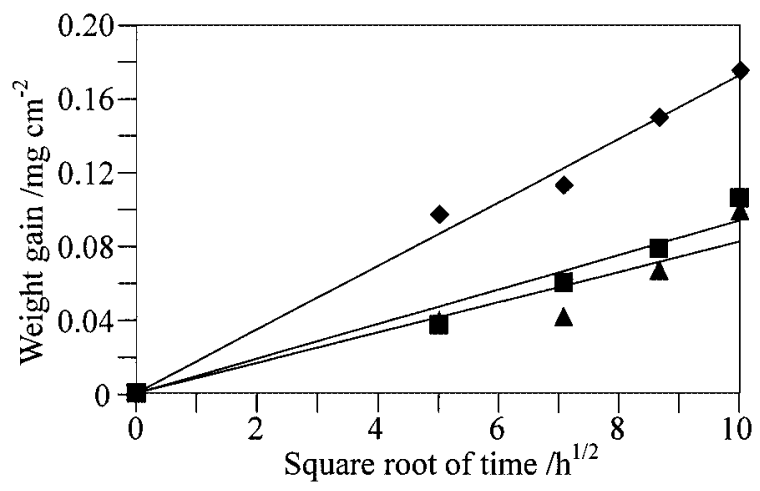

Fig. 3. Cycling oxidation behaviors of the uncoated sample $(\checkmark)$, single coated sample $(\mathbf{\square})$, and triple coated sample $(\boldsymbol{\Delta})$ (at $1500^{\circ} \mathrm{C}$ for up to $100 \mathrm{~h}$ in air).
(A)

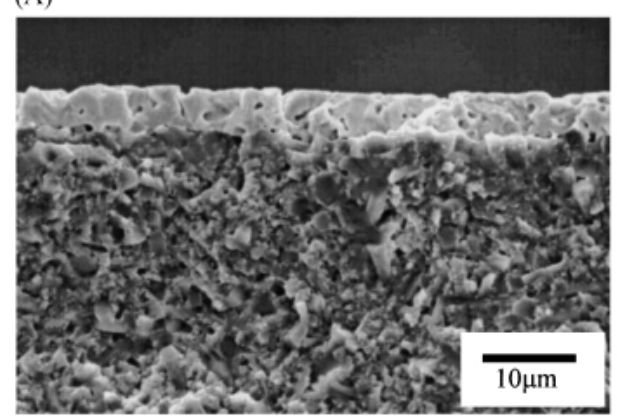

(B)

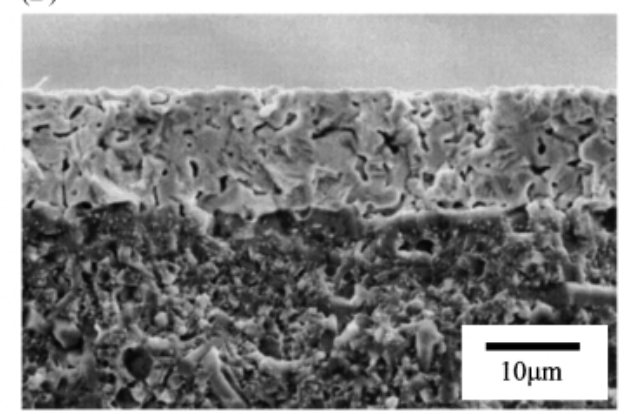

Fig. 2. SEM micrographs of cross section of the single coated (A) and triple coated (B) samples fabricated by reaction sintering after dip coating. 

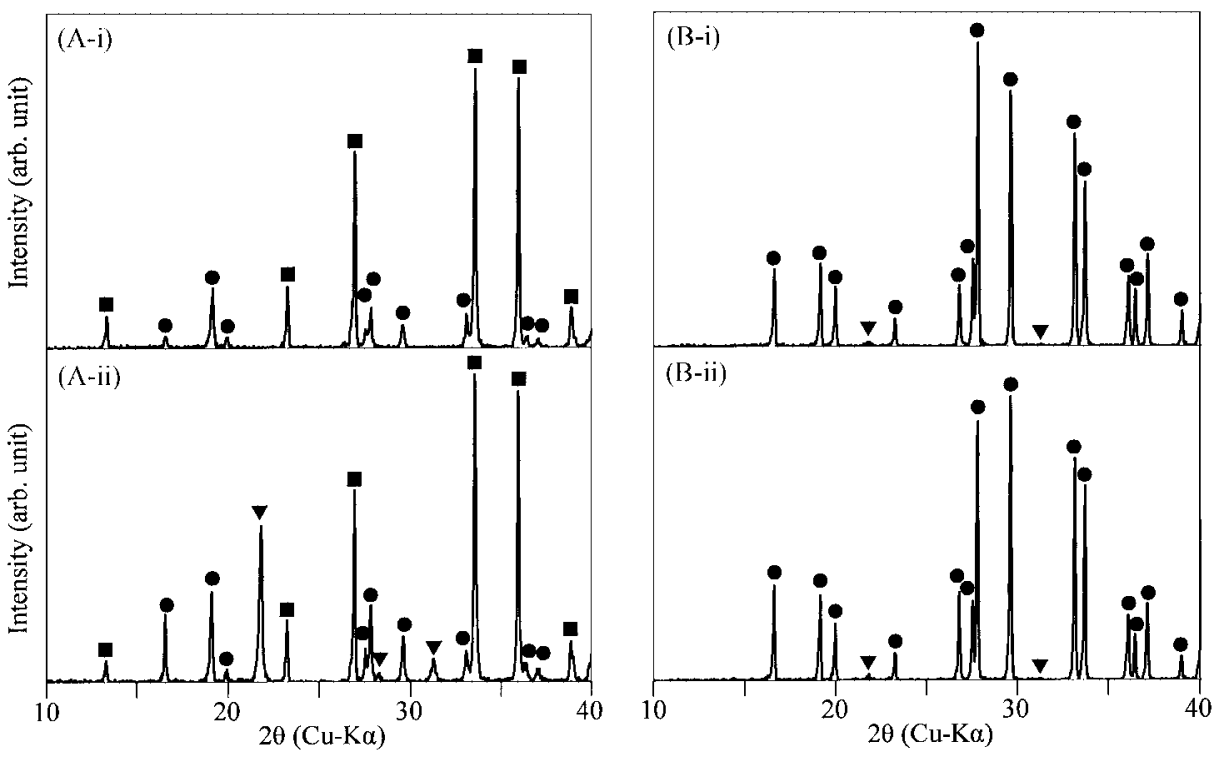

Fig. 4. XRD patterns of the uncoated (A) and triple coated (B) samples before (i) and after (ii) cycling oxidation at $1500^{\circ} \mathrm{C}$ for $100 \mathrm{~h}$ in air $\left(\mathrm{Lu}_{2} \mathrm{Si}_{2} \mathrm{O}_{7}(34-0509), \mathrm{SiO}_{2}(\nabla 39-1425), \beta-\mathrm{Si}_{3} \mathrm{~N}_{4}(\square 33-1160)\right)$.

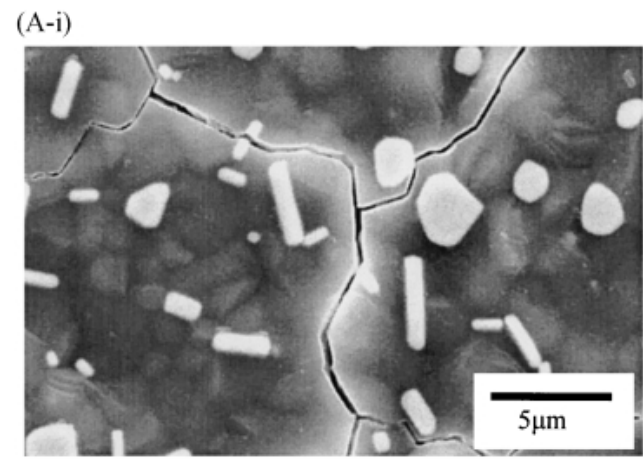

(B-i)

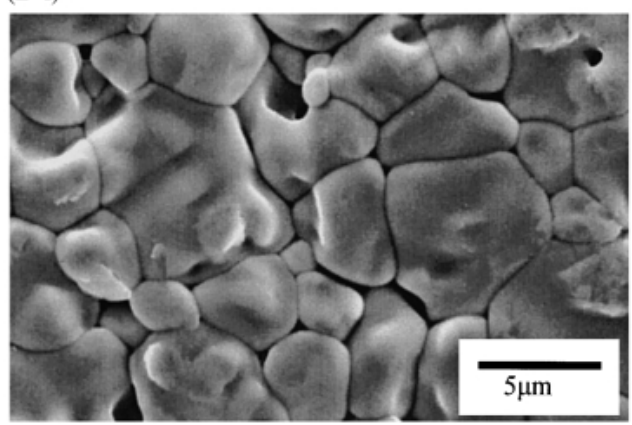

(A-ii)

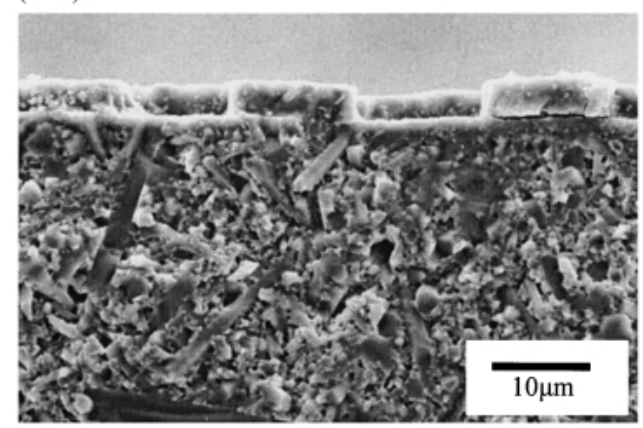

(B-ii)

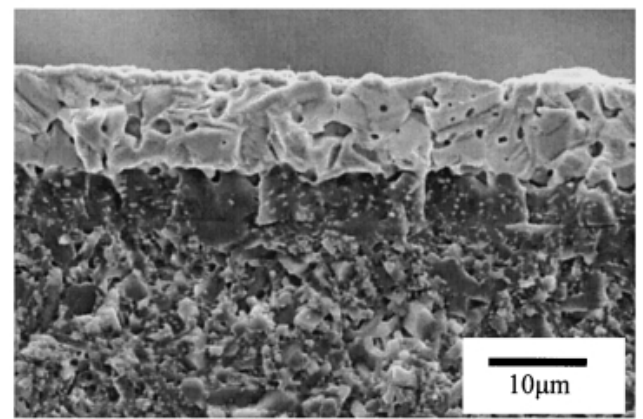

Fig. 5. SEM micrographs of the uncoated (A) and triple coated (B) samples after cycling oxidation at $1500^{\circ} \mathrm{C}$ for $100 \mathrm{~h}$ in air ( (i) surface, (ii) cross section).

phases increased remarkably after the cycling oxidation. It is considered that $\mathrm{SiO}_{2}$ phase was formed by oxidation of $\mathrm{Si}_{3} \mathrm{~N}_{4}$ substrate and reacted with remaining $\mathrm{Lu}_{2} \mathrm{O}_{3}$ or related elements at grain boundary of the substrate to produce $\mathrm{Lu}_{2} \mathrm{Si}_{2} \mathrm{O}_{7}$. On the other hand, in the case of the triple coated sample, $\mathrm{SiO}_{2}$ phase increased little, indicating that $\mathrm{Lu}_{2} \mathrm{Si}_{2} \mathrm{O}_{7}$ layer protected the $\mathrm{Si}_{3} \mathrm{~N}_{4}$ substrate from oxidation. The good oxidation resistance of the coated samples was also confirmed by SEM observation for the surface and cross section of the triple coated sample after the oxidation as shown in Fig. 5. In the case of the uncoated sample, $\mathrm{SiO}_{2}$ scale with a thickness of about $3 \mu \mathrm{m}$ formed with $\mathrm{Lu}_{2} \mathrm{Si}_{2} \mathrm{O}_{7}$ particles, and the surface was cracked. This is because of large mismatch in coefficients of thermal expansion between the scale and substrate. In contrast, it is noticed that the $\mathrm{Lu}_{2} \mathrm{Si}_{2} \mathrm{O}_{7}$ layer protected well the $\mathrm{Si}_{3} \mathrm{~N}_{4}$ substrate in the case of the triple coated sample. The layer was densified with a thickness of about $10 \mu \mathrm{m}$, which was less than that before the oxidation test. This indicates that further sintering of $\mathrm{Lu}_{2} \mathrm{Si}_{2} \mathrm{O}_{7}$ progressed during oxidation, and that oxidation resistance of $\mathrm{Si}_{3} \mathrm{~N}_{4}$ would improve further by 


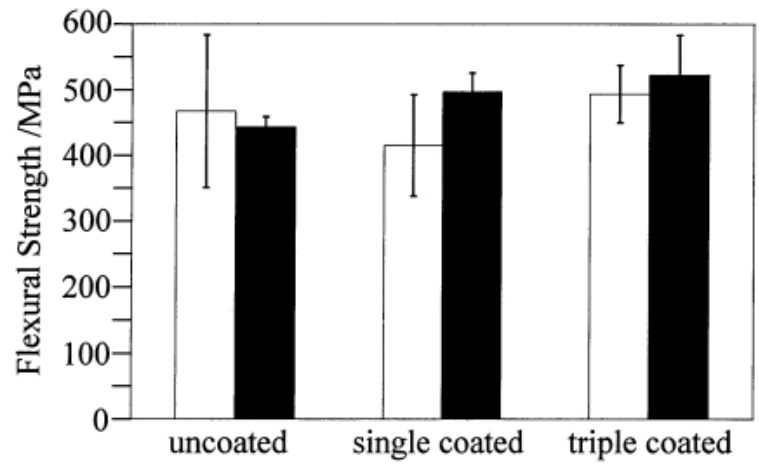

Fig. 6. Flexural strengths of the uncoated, single coated, and triple coated samples before $(\square)$ and after $(\square)$ cycling oxidation at $1500^{\circ} \mathrm{C}$ for $100 \mathrm{~h}$ in air. Error bars stand for \pm 1 standard deviations.

fabricating more densified $\mathrm{Lu}_{2} \mathrm{Si}_{2} \mathrm{O}_{7}$ layer in the future.

Figure 6 shows the flexural strength of the uncoated, single coated, and triple coated samples before and after the cycling oxidation test at $1500^{\circ} \mathrm{C}$ for $100 \mathrm{~h}$ in air. The flexural strength of the coated sample was not deteriorated before the oxidation in comparison with that of the uncoated one, although that of single coated one was relatively low with a large standard deviation. It was also maintained after the oxidation, whereas the strength of the uncoated sample was deteriorated a little because of the cracked surface by the formation of $\mathrm{SiO}_{2}$ scale. The small improvements of the strengths of the coated samples after the oxidation were probably because of the healing of the defects inside the substrate during the oxidation. These results indicate that the coating layer of $\mathrm{Lu}_{2} \mathrm{Si}_{2} \mathrm{O}_{7}$ protected $\mathrm{Si}_{3} \mathrm{~N}_{4}$ from oxidation.

\section{Conclusion}

$\mathrm{Lu}_{2} \mathrm{Si}_{2} \mathrm{O}_{7}$ layer of $4-12 \mu \mathrm{m}$ in thickness with a small amount of $\mathrm{SiO}_{2}$ phase was coated by reaction sintering after dip coating. The oxidation resistance and flexural strength of the coated samples were investigated and compared with those of the uncoated sample.

Although the fabricated layer was somewhat porous, the total weight gain of the coated sample was almost half that of the uncoated sample after the cycling oxidation test at $1500^{\circ} \mathrm{C}$ for up to $100 \mathrm{~h}$ in air, indicating that oxidation resistance of $\mathrm{Si}_{3} \mathrm{~N}_{4}$ was improved by about $100 \%$. The improvement of the oxidation resistance can be attributed to the $\mathrm{Lu}_{2} \mathrm{Si}_{2} \mathrm{O}_{7}$ layer, which protected $\mathrm{Si}_{3} \mathrm{~N}_{4}$ substrate from oxidation. The weight gain became less when the coating layer was thicker, but the effect of thickness on preventing the oxidation was relatively small. The flexural strength of the coated sample was not deteriorated in comparison with that of the uncoated one. It was also maintained after the cycling oxidation at $1500^{\circ} \mathrm{C}$ for $100 \mathrm{~h}$ in air. Those physical and chemical stabilities can be attributed to the presence of $\mathrm{Lu}_{2} \mathrm{Si}_{2} \mathrm{O}_{7}$ layer, which effectively prevents oxidation of $\mathrm{Si}_{3} \mathrm{~N}_{4}$.

Acknowledgements This work has been supported by METI, Japan, as part of the Synergy Ceramics Project. Part of the work has been supported by NEDO. The authors are members of the Joint Research Consortium of Synergy Ceramics. The authors acknowledge gratefully Masahiro Asayama, Seiichi Suenaga, and Takayuki Fukasawa of Toshiba Corp. and Shunkichi Ueno of National Institute of Advanced Industrial Science and Technology, for their kind help.

\section{References}

1) Tsuge, A., Nishida, K. and Komatsu, M., J. Am. Ceram. Soc., Vol. 58, pp. 323-326 (1975).

2) Sanders, W. A. and Mieskowski, D. M., Am Ceram. Soc. Bull., Vol. 64, pp. 304-309 (1985).

3) Guo, S., Hirosaki, N., Yamamoto, Y., Nishimura, T. and Mitomo, M., Scripta Materialia, Vol. 45, pp. 867-874 (2001).

4) Mieskowski, D. M. and Sanders, W. A., J. Am. Ceram. Soc., Vol. 68, pp. C160-C163 (1985).

5) Park, H., Kim, H.-W. and Kim, H.-E., J. Am. Ceram. Soc., Vol. 81, pp. 2130-2134 (1998).

6) Klemm, H. and Schubert, C., J. Am. Ceram. Soc., Vol. 84, pp. 2430-2432 (2001).

7) Cinibulk, M. K., Thomas, G. and Johnson, S. M., J. Am. Ceram. Soc., Vol. 75, pp. 2044-2049 (1992). 